\title{
Farmers' Perceptions about the Effect of Farm Land Management Practices and Soil Depth on the Distribution of Major Soil Physico-Chemical Properties in Eroded Soils of Aboy Gara Watershed, Gidan District, North Wollo Zone
}

\author{
Gebeyaw Tilahun Yeshaneh \\ Department of Soil and Water Resources Management, Faculty of Agriculture, Woldia University, Ethiopia \\ Corresponding Author: gebeyaw2006@yahoo.com
}

\begin{abstract}
The study was conducted at the Abuhoy Gara Catchment, which is located in the Gidan District of North Wello Zone. The aim of the study was to study farmers' perceptions about the effect of farm land management practices and soil depth on the distribution of major soil physico-chemical properties in eroded soils of Aboy Gara watershed. To address this issue, semi-structured interviews were conducted in 64 households to gain insight into soil fertility management practices, local methods were used to assess the fertility status of a field, and perceived trends in soil fertility. Thirty-three farmers were then asked to identify fertile and infertile fields. According to farmers response, farmers' fields were characterized as fertile where it comprise black color, cracks during dry season, good crop performance, vigorous growth of certain plants and presence of plants in a dry environment whereas the infertile is where it shows yellow/white and red colors, compacted soils, stunted plant growth, presence of rocks and stones and wilting or dying of crops in a hot environment. A total of eight indicators (soil color, texture, soil depth, topography, soil drainage, and distance from home, type of weeds grown and cultivation intensity) were found to be used by farmers to evaluate and monitor soil fertility. The results of administered questions showed that the principal indicators mentioned by farmers as very important were soil colour (82.8\%), continuous cropping land (72.2\%), soil texture $(62.8 \%)$, distance from home $(61 \%)$, type of weeds grown (56\%), soil depth (55.6\%), topography (51.1\%), and soil drainage $(28.7 \%)$ as very important. So, among sixty four interviewed farmers: deep soil (60 farmers), soils near to home (60 farmers), forest soil (59 farmers), smooth fine soil (59 farmers), black color soil (58 farmers) and gentle slope soil (57farmers) are categorized as fertile whereas 59, 57, 56, 55, and 44farmers said that Sandy/coarse soil, shallow soil depth, steep slope soils and yellow/white, red soils and continuously cultivated soils are infertile, respectively. The overall result showed that there was good agreement between farmers' assessment of the soil fertility status of a field and a number of these indicators. The soil laboratory analysis also corresponded well with farmers' assessment of soil fertility. Therefore, to design more appropriate research and to facilitate clear communication with farmers, researchers need to recognize farmers' knowledge, perceptions about assessments of soil fertility. Because, as they included all soil factors affecting plant growth, farmers' perceptions of soil fertility were found to be more long term day-to-day close practical experience finding than those of researchers.
\end{abstract}

Keywords: Farmers' perceptions, Soil fertility, Physico-chemical properties, Indicators, Eroded soils, Watershed

\subsection{Introduction}

The Ethiopian economy and the livelihoods of its population depend heavily on agriculture sector; efforts to sustain and improve the sector's productivity are therefore crucial to the country's economic development and to the welfare of its people. Securing food and a livelihood is inextricably linked to the exploitation of the natural resource base (land, water and forest) in Ethiopia, where over 85 
percent of the population lives in rural areas and contribute significantly to the total export value (Alemneh, 2003). The pressure of intense human activity and improper farming and management practices pose serious threats to the sustainability and the suitability of soil for crop production which is based on the quality of the soil's physical, chemical and biological properties.

Land degradation, mainly due to soil erosion and nutrient depletion, has become one of the most important environmental and economic problems in the highlands of Ethiopia. And it was estimated that half of the Ethiopian highlands' arable lands are moderately to severely degraded and nutritionally depleted due to over cultivation, over grazing, primitive production techniques, and over dependent on rainfall (Hugo et al., 2002). According to World Bank (2008), Ethiopia high lands including the study areas are most seriously affected by land degradation resulting in low and declining agricultural productivity, persistent food insecurity and rural poverty. The complex interlinkages between environmental degradation, poverty and fast population growth have brought several changes (Dasgupta and Mäler, 1994) like farm holdings becoming smaller and more fragmented, fallow periods becoming shorter, farmers cultivating fragile margins on steep slopes previously held in pasture and woodlot.

In order to give a sustainable solution to all these challenges, collaborative research between researchers and farmers is very crucial. However, until recently, farmers' knowledge of soil fertility has been largely ignored by soil professionally biased researchers. Hence, their adoption of improved techniques has been limited and biased (Shrestha et al., 2000). But with increasing use of participatory research approaches, it is becoming clear that farmers have a well- developed ability to perceive differences in the level of fertility between and within fields on their farms. They also see the actual fertility of a soil at any time as a function not only of these longer-term soil properties, but also of the current and past management regime. As such, they assess the fertility of the soil using a range of indicators which they can actually see or feel, including crop yields, soil depth, drainage, moisture, manure requirements, water source, slope, and weed abundance. Therefore the findings of this paper can build cooperative researches with farmers' perceptions about the assessment of soil fertility in a more detail way in line with the criteria of soil fertility used by researchers. Therefore, the objective of the study was to study farmers' perceptions about the effect of farm land management practices and soil depth on the distribution of major soil physico-chemical properties in eroded soils of Aboy Gara watershed.

\subsection{Methodology}

\subsection{Description of study area}

The study was conducted at Abuhoy Gara catchment in Gidan district (Figure 1) which is found in North Wollo Zone of Amhara National Regional State. Gidan is bordered by Tigray Region in the North; Gubalafto district in the North east; Meket district in the south east and Lasta district in the south and south west. Astronomically, it is located between $11^{\circ} 53^{\prime}-12^{\circ} 16^{\prime}$ North and $39^{\circ} 10^{\prime}-39^{\circ} 35^{\prime}$ east $39^{\circ} 10^{\prime}-39^{\circ} 35^{\prime}$ East. Muja is the administrative town of the district and is situated at about $595 \mathrm{~km}$ from the capital city, Addis Ababa. According to the district agricultural office report, the population of the study catchment is 580 people of whom 420 are male and 160 are female. The total area of Abuhoy Gara catchment is about 615 hectares (250 hectares cultivated and 365 hectares none cultivated lands). According to north-east Amhara meteorological data survives, the annual mean rainfall is $1100 \mathrm{~mm}$ with the annual mean maximum and minimum temperature of $21.23^{\circ} \mathrm{C}$ and $9.57^{\circ} \mathrm{C}$, respectively. The topography and land form of the area is dominated by rolling hills dissected streams and valleys. The altitude ranges from 3,089 to 3,559 m.a.s.l (having an average altitude 3,324 m.a.s.l). The topography of the watershed (i.e., at total of 1819 ha) is characterized as $15 \%$ gentle slopes, 53.6\% steep slope, $31.4 \%$ very steep. Rained subsistence farming is the dominant form of agriculture coupled with livestock keeping. Dominant crops include wheat, barley and faba bean cultivated during the main rainy season. Livestock production is an essential part of the farming system. Most farm households keep cattle dominated by oxen and small stock including sheep, poultry, and equines. 


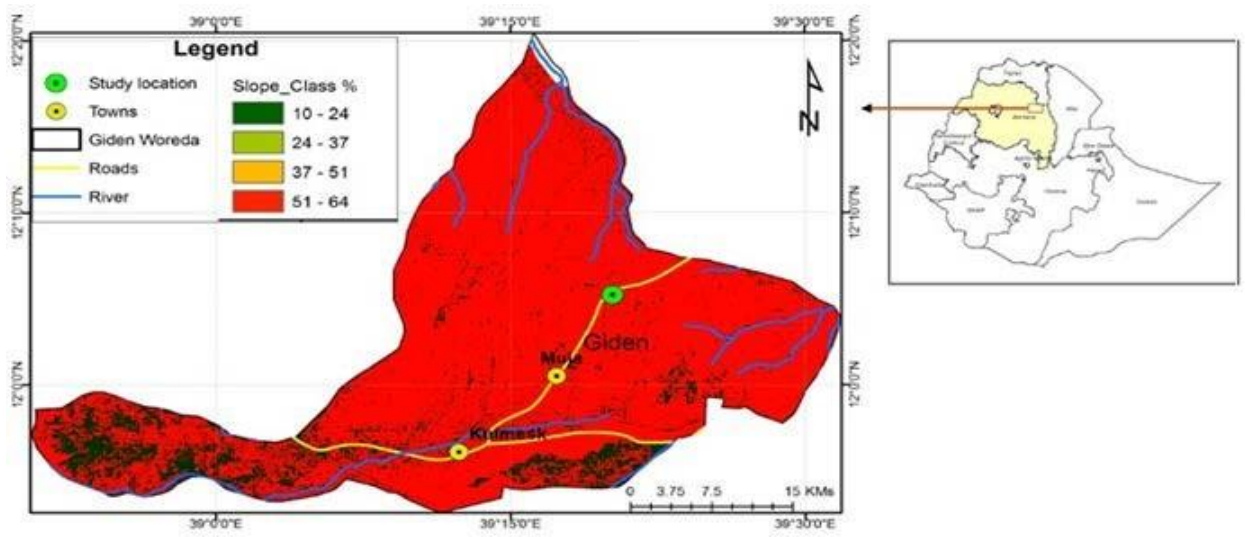

Figure 1: Location map of the study area

\subsection{Methods of data collection}

\subsubsection{Field observation and household interviews}

At the beginning, a general visual field survey of the area was carried out to have a general view of the study area. Global Positioning System readings were used to identify the geographical locations and the coordinate system where data could be taken, and clinometers were used to identify slopes of the sampling sites. In order to capture the local indicators and farmers' perception of soil fertility on the study site, participatory rural appraisal tools were conducted using namely direct observation, formal and informal discussion, focus group interviews and key informants. Some limited field work was also undertaken to verify some of the information and data gathered during the discussions and interviews. On the identification of the local indicators of soil fertility through interviews with local people, the soils were broadly categorized into two groups: fertile (ertib) soils and infertile (koda) soils with respect to crop yields. Indicators were related to management induced changes in the soil which includes only those properties relevant to the soil types, farming system, and land uses of the areas. Therefore, questionnaire survey was administered to 64 sampled households (43 males, 21 female) to capture information on farmers' perceptions about the fertility status of their farm lands. The sampled households who having a minimum of 0.75 hectares of land size with an average experience of 20 year were randomly selected from a list of total households collected from the representatives of each village. Special care was taken to ensure that the most experienced member of the household is being interviewed. Fields that were rented out to other farmers, or fields that were being rented by the interviewee, were excluded from the discussions to minimize errors due to a possible lack of knowledge regarding the management of these fields. To increase the validity and reliability of data, focus group discussions (composed of elders, male and female farmers and community leaders) and informal interviews with developmental agents and district agricultural experts were carried out. Secondary sources of data were gathered from unpublished documents and official reports from relevant government offices.

\subsubsection{Soil sampling}

Before sampling, forest litter, grass, dead plants and any other materials on the soil surface were removed and during collection of samples, field/terrace edges, furrow, old manures, wet spots, areas near trees, compost pits, fields used as kitchen gardens and fertilizer bands were excluded. From those interviewed, a subset of 33 farmers were selected at random and asked to indicate their most fertile field and their most infertile field. Each of these fields and its surrounding environment was then characterized according to its distance from the household, its size, terrace height, tree shade, stoniness, aspect of crops, and hardness of the soil felt when sampling. Representative soil sampling sites were purposely selected based on cultivation history and indigenous local indicators of soil fertility groups using farmers' perceptions'. In order to determine the impact of management practices and depth on the distribution of soil physic-chemical properties, a total of 42 composite soil samples were collected by flexible gridding system (flexible grid survey method of 1:30,000 scales throughout the field at two depths, surface $(0-15 \mathrm{~cm})$ and subsurface $(15-30 \mathrm{~cm})$ soil layers) (Ryan et al., 2001). The number and distribution of soil samples were determined using Global Positioning mapping system based on the identified soil fertility groups (fertile and infertile). Soil sampling was based on 
the identified soil fertility groups. In each soil group, a composite soil sample of 10 sub-samples was taken from each soil depth $(0-15$ and $15-30 \mathrm{~cm})$.

\subsection{Method of data analyses}

\subsubsection{Soil laboratory analysis}

The collected samples were air-dried, homogenized and sieved to pass a $2 \mathrm{~mm}$ mesh sieve for physical and chemical analyses. Particle-size distribution was determined using the pipette methods or hydrometer method (Gee and Bauder, 1986). Soil $\mathrm{pH}$ was determined in water (1M potassium chloride in a soil to solution ratio of 1: 2.5 soil water solution (McLean, 1982) using glass electrodes after reciprocal shaking for 1 hour). The exchangeable acidity was extracted with $1 \mathrm{M}$ potassium chloride $(\mathrm{KCl})$ and it can be determined by the titration method using $0.01 \mathrm{M}$ sodium hydroxide $(\mathrm{NaOH})$ (Sumner and Stewart, 1992). Organic matter and total organic carbon were determined using loss-on-ignition method (Corbeels et al., 2000). Total nitrogen was determined using Kjeldahl method (Okalebo et al., 1993) and total carbon in soil was determined by the wet digestion method of Walkley and Black (Bremner and Mulvaney, 1982; Nelson and Sommers, 1982). Olsen et al. (1954) and Bray II method (Kuo, 1996) was used to determine available phosphorous content of the soil. Exchangeable cations (potassium, calcium, magnesium and sodium) were extracted with $1 \mathrm{M}$ Ammonium acetate (NH4OAc) buffered at $\mathrm{pH}$ 7. The concentrations of potassium, calcium, magnesium and sodium in the solutions were measured by atomic absorption spectrophotometer (Shimadzu AA-6800). The cation exchange capacity of the soil was determined by $0.05 \mathrm{M}$ potassium sulphate $\left(\mathrm{K}_{2} \mathrm{SO}_{4}\right)$ using the soil used for the basic exchangeable cation determination or by the neutral ammonium acetate (CH3COONH4) saturation method (Ryan et al., 2001). The exchangeable bases in the ammonium acetate filtrates collected above were measured by atomic absorption spectrophotometer (Ryan et al., 2001).

\subsubsection{Data analysis}

Analysis of variance (ANOVA) using the general linear model procedure of the statistical analysis system (SAS) was performed to detect soil physicochemical properties differences on the surface soils $(0-15 \mathrm{~cm})$ and subsurface soil $(15-30 \mathrm{~cm})$ of fertile $(e r t i b)$ and infertile (koda) soil groups. The data generated by structured questionnaires were analyzed using descriptive analysis to describe and investigate the characteristics of the farmers' perception.

\subsection{Results and Discussion}

\subsection{Farmers' Perceptions about Soil Fertility}

Farmers in the study area have almost common criteria to evaluate and identify their soils. Usually, fields were characterized as fertile (ertib) or infertile (koda). They used soil color, texture, soil depth, soil drainage, topography and distance from home as criteria to classify the soil into different groups (Table 1). Based on these criteria farmers of the catchment categorized their soils into: fertile (ertib) and infertile $(k o d a)$.

Soil color is an important criterion for farmers, whereas with respect to soil texture, farmers preferred heavy soils (clay soils) to sandy soils because of their high water holding capacity and nutrients of plants. Sandy soils are mostly highly weathered and their physical, chemical and biological attributes of soil fertility are extremely limited (Brady and Weil, 2002). According to farmers response, farmers' fields were characterized as fertile (ertib) where it comprise black color, cracks during dry season, good crop performance, vigorous growth of certain plants and presence of plants in a dry environment and as infertile (koda) where it shows yellow/white and red colors, compacted soils, stunted plant growth, presence of rocks and stones and wilting or dying of crops in a hot environment. On the other hand, fifty five farmers said that white and red soils were most commonly used to describe infertile (koda) soils. The reason was because of its low water holding capacity; making it less productive in low rainfall years and low nutrient retention capacities. So, sixty-four interviewed farmers for each type of soil, 60, 60, 59, 59, 58 and 57 said deep soil, soils near to home, forest soil, smooth fine soil, black color soil and gentle slope soil are fertile, respectively whereas 59, 57, 56, 55, and 44 farmers said that sandy/coarse soil, shallow soil depth, steep slope soils and yellow/white, red soils and continuously cultivated soils are infertile, respectively (Table 1). According to farmers in the area, 
these red and light-colored soils have acidic soil reactions and non-productive soils. The occurrence of light and red-colored soils is related to very low organic matter content and significant amounts of iron and aluminum oxides and hydroxides in the soil Pawluk et al. (1992).

Table 1: Soil types identified by farmers using possible indicators $(n=64)$

\begin{tabular}{|l|l|l|l|}
\hline Local indicators & Fertile $($ ertib $)$ & Infertile $($ koda $)$ & Undecided \\
\hline Yellow/white and red & 5 & 57 & 2 \\
\hline Black ('Koticha) & 58 & 4 & 2 \\
\hline Light black & 39 & 21 & 4 \\
\hline Brown Dalacha' soil & 31 & 30 & 3 \\
\hline Steep slope soil & 4 & 55 & 5 \\
\hline Gentle slope & 57 & 4 & 3 \\
\hline Deep soil depth & 60 & 3 & 1 \\
\hline Shallow soil depth & 2 & 57 & 1 \\
\hline Swampy soil & 1 & 56 & 3 \\
\hline Well drained soil & 57 & 3 & \\
\hline Sandy/coarse soil & 1 & 59 & \\
\hline Smooth fin soil & 59 & 2 & 3 \\
\hline Soils around near to home & 60 & 4 & \\
\hline Continuously cultivated soils & 8 & 44 & 4 \\
\hline Grazing land soils & 41 & 17 & 6 \\
\hline Forest soils & 59 & 5 & \\
\hline
\end{tabular}

\subsection{Farmer Indicators of Soil Fertility}

The results of administered questions showed that the principal indicators mentioned by farmers (Table 2) were soil colour (82.8\% of the farmers), continuous cropping land (72.2\%), soil texture $(62.8 \%)$, distance from home (61\%), type of weeds grown (56\%), soil depth (55.6\%), topography $(51.1 \%)$, and soil drainage (28.7\%) as very important. Similar to Corbeels et al. (2000) farmers were found to classify their soils very importantly according to their colour relatively than texture and others (Table 1 and Table 2).

Table 2: Indicators rank based on their importance

\begin{tabular}{|l|l|l|l|l|l|}
\hline \multirow{2}{*}{ Indicators } & \multicolumn{5}{|c|}{ Rank based on farmers' perceptions } \\
\cline { 2 - 6 } & Very important & Important & Undecided & Least important & Not important \\
\hline Soil color & $149 / 180=82.8 \%^{(1 \mathrm{st})}$ & $15 / 180=8.3 \%^{(8 \mathrm{th})}$ & $16 / 180=8.9 \%$ & & - \\
\hline Soil Texture & $113 / 180=62.8 \%^{(3 \mathrm{rd})}$ & $36 / 180=20 \%^{(6 \mathrm{th})}$ & $10 / 180=5.6 \%$ & $14 / 180=7.8 \%$ & $7 / 180=3.9 \%$ \\
\hline Soil Depth & $100 / 180=55.6 \%^{(6 \mathrm{th})}$ & $39 / 180=21.7 \%^{(5 \mathrm{th})}$ & $8 / 180=4.4 \%$ & $18 / 180=10 \%$ & $15 / 180=8.3 \%$ \\
\hline Topography & $92 / 180=51.1 \%^{(7 \mathrm{th})}$ & $47 / 180=26 \%^{(4 \mathrm{th})}$ & $22 / 180=12.2 \%$ & $18 / 180=10 \%$ & $1 / 180=0.6 \%$ \\
\hline Soil Drainage & $52 / 180=28.9 \%^{(8 \mathrm{th})}$ & $48 / 180=26.7 \%^{(3 \mathrm{rd})}$ & $51 / 180=28.3 \%$ & $21 / 180=11.7 \%$ & $8 / 180=4.4 \%$ \\
\hline Farm distance & $112 / 180=61 \%^{(4 \mathrm{th})}$ & $29 / 180=16.1 \%^{(7 \mathrm{th})}$ & $8 / 180=4.4 \%$ & $23 / 180=12.8 \%$ & $8 / 180=4.4 \%$ \\
\hline Continuous cropping & $131 / 180=72.7 \%^{(2 \mathrm{nd})}$ & $49 / 180=27.2 \%^{(2 \mathrm{nd})}$ & & & \\
\hline Type of weeds & $101 / 180=56 \%^{(5 \mathrm{th})}$ & $72 / 180=40 \%^{(1 \mathrm{st})}$ & & $7 / 180=3.9 \%$ & \\
\hline
\end{tabular}

\subsection{Farmers Perceptions and Laboratory Results}

\section{Soil Texture:}

There were no significant differences in sand and clay particle size distribution among /between the two soil groups (fertile and infertile), but the highest mean sand fraction and clay fraction were observed in infertile and fertile soils, respectively (Table 3). The increasing of clay fraction and decreasing of sand fraction indicates that these have positive correlation with soil fertility. This is apparent because the clay particles unlike the sand particles, have substantial exchange surface areas, and therefore adsorb and stabilize organic matter and soil nutrients (Saggar et al., 1994; Saggar et al., 1996). 
Table 3: Selected soil physical characteristics of farmer designated ertib (fertile) and koda (infertile) soils

\begin{tabular}{|c|c|c|c|}
\hline \multirow[b]{2}{*}{ Variables } & Sand \% & Silt \% & Clay \% \\
\hline & \multicolumn{3}{|c|}{ Farmers' Perception } \\
\hline Fertile soil & $59.17 \mathrm{a}$ & $16.25 \mathrm{a}$ & $24.58 \mathrm{a}$ \\
\hline Infertile soil & $60.00 \mathrm{a}$ & $16.25 \mathrm{a}$ & $23.75 \mathrm{a}$ \\
\hline $\operatorname{LSD}(0.05)$ & NS & NS & NS \\
\hline SEM (+) & 29.1667 & 3.4722 & 15.9722 \\
\hline CV (\%) & 9.0640 & 11.4670 & 16.5374 \\
\hline \multicolumn{4}{|c|}{ Soil Depth } \\
\hline $0-15 \mathrm{~cm}$ & $57.92 \mathrm{a}$ & $18.33 \mathrm{a}$ & $23.75 \mathrm{a}$ \\
\hline $15-30 \mathrm{~cm}$ & $61.25 \mathrm{a}$ & $14.17 \mathrm{~b}$ & $24.58 \mathrm{a}$ \\
\hline $\operatorname{LSD}(0.05)$ & NS & 2.633 & NS \\
\hline $\operatorname{SEM}(+)$ & 29.1667 & 3.4722 & 15.9722 \\
\hline
\end{tabular}

*Values with the same letter are not significantly different $(P<0.05)$; SEM $=$ Standard Error of Mean; LSD $=$ Least Significance Difference; $C V=$ Coefficient of Variation

Table 4: Interaction effects of farmers' perception and soil depth on selected soil physical properties

\begin{tabular}{|c|c|c|c|c|c|c|}
\hline \multirow{3}{*}{ Variables } & \multirow{2}{*}{\multicolumn{2}{|c|}{$\begin{array}{c}\text { Sand }(\%) \\
\text { Soil Depth }(\mathrm{cm})\end{array}$}} & \multirow{2}{*}{\multicolumn{2}{|c|}{$\begin{array}{c}\text { Silt }(\%) \\
\text { Soil Depth }(\mathrm{cm})\end{array}$}} & \multirow{2}{*}{\multicolumn{2}{|c|}{$\begin{array}{c}\text { Clay }(\%) \\
\text { Soil Depth }(\mathrm{cm})\end{array}$}} \\
\hline & & & & & & \\
\hline & $0-15$ & $15-30$ & $0-15$ & $15-30$ & $0-15$ & $15-30$ \\
\hline Fertile soil & $58.55 \mathrm{a}$ & $60.21 \mathrm{a}$ & $17.29 \mathrm{a}$ & $15.20 \mathrm{ab}$ & $24.17 \mathrm{a}$ & $24.58 \mathrm{a}$ \\
\hline Infertile soil & $58.96 a$ & $60.63 a$ & $17.29 \mathrm{c}$ & $15.21 b c$ & $23.75 \mathrm{a}$ & $24.16 \mathrm{a}$ \\
\hline $\operatorname{LSD}(0.05)$ & \multicolumn{2}{|c|}{ NS } & \multicolumn{2}{|c|}{3.723} & \multicolumn{2}{|c|}{ NS } \\
\hline SEM (土) & \multicolumn{2}{|c|}{29.1667} & \multicolumn{2}{|c|}{3.4722} & \multicolumn{2}{|c|}{15.9722} \\
\hline CV (\%) & \multicolumn{2}{|c|}{9.0640} & \multicolumn{2}{|c|}{11.4670} & \multicolumn{2}{|c|}{16.5373} \\
\hline
\end{tabular}

*Values with the same letter are not significantly different $(P<0.05) ; L S D=$ Least Significance Difference; SEM $=$ Standard Error of Mean; $C V=$ Coefficient of Variation

Soil chemical properties:

According to farmers' perception, fields can be classified as fertile (ertib) and infertile (koda) based on different local indicators. There was significance difference in soil exchangeable cations (calcium, magnesium, potassium), cation exchange capacity, total nitrogen, organic carbon and available phosphorous between soils classified as fertile (ertib) and infertile (koda) by farmers, while no significance difference in soil exchangeable sodium and acidity and $\mathrm{pH}$ (Table 5 ). Considering the two soil groups (ertib and koda), the higher mean values of calcium $\left(7.88 \mathrm{cmol}(+) \mathrm{kg}^{-1}\right)$, magnesium $\left(1.97 \mathrm{cmol}(+) \mathrm{kg}^{-1}\right)$, potassium $\left(0.78 \mathrm{cmol}(+) \mathrm{kg}^{-1}\right)$, sodium $\left(0.29 \mathrm{cmol}(+) \mathrm{kg}^{-1}\right)$, cation exchange capacity $\left(15.57 \mathrm{cmol}(+) \quad \mathrm{kg}^{-1}, \mathrm{pH}-\mathrm{H}_{2} \mathrm{O}(6.01)\right.$, total nitrogen $(0.116 \%)$, organic carbon $(1.583 \%)$ and available phosphorous $(8.33 \mathrm{ppm})$ were observed within the fertile (ertib) soils while the highest mean value of exchangeable acidity $\left(0.263 \mathrm{cmol}(+) \mathrm{kg}^{-1}\right)$ was observed on infertile $($ koda $)$ soils (Table 5). This result is in agreement with other studies, for instance, Murage et al. (2000) found in Kenya that productive soils (fertile soils), as identified by farmers, had significantly higher soil $\mathrm{pH}$, effective cation exchange capacity, exchangeable cations, extractable phosphorus, and total nitrogen than nonproductive soils (infertile soils). According to the classification of soil chemical properties as per the ranges suggested by FAO (2006), Jones (2003), Landon (1991), Tekalign (1991), Barber (1984) and Murphy (1968), the soils of Abuhoy Gara Catchment was moderate content in calcium (5-10 cmol $(+)$ $\left.\mathrm{kg}^{-1}\right)$, cation exchange capacity $\left(12-25 \mathrm{cmol}(+) \mathrm{kg}^{-1}\right)$, potassium $\left(0.3-0.7 \mathrm{cmol}(+) \mathrm{kg}^{-1}\right)$, magnesium (1-3 cmol $\left.(+) \mathrm{kg}^{-1}\right)$, $\mathrm{pH}-\mathrm{H}_{2} \mathrm{O}$ (5.6-6.0), whereas low in sodium $\left(0.1-0.3 \mathrm{cmol}(+) \mathrm{kg}^{-1}\right)$, total nitrogen $(0.05-0.15 \%)$, available phosphorus (1-9 ppm), and organic carbon $(1-2 \%)$. Thus these results showed that there was no significantly difference between both perceptions of researchers and farmers. 
Table 5: Selected soil chemical characteristics of farmer designated fertile soil and infertile soil

\begin{tabular}{|c|c|c|c|c|c|c|c|c|c|c|}
\hline \multirow{2}{*}{ Variables } & \multicolumn{10}{|c|}{ Exchangeable $\left(\mathrm{cmol}(+) \mathrm{kg}^{-1}\right)$} \\
\hline & $\mathrm{Ca}$ & $\mathrm{Mg}$ & K & $\mathrm{Na}$ & Exa.A & CEC & $\mathrm{pH}-\mathrm{H}_{2} \mathrm{O}$ & $\mathrm{TN} \%$ & OC\% & Av. $\mathrm{P}(\mathrm{ppm})$ \\
\hline \multicolumn{11}{|c|}{ Farmers' Perception about soil fertility } \\
\hline Fertile soil & $7.88 \mathrm{a}$ & $1.97 \mathrm{a}$ & $0.78 \mathrm{a}$ & $0.29 a$ & $0.215 \mathrm{a}$ & $15.57 \mathrm{a}$ & $6.01 \mathrm{a}$ & $0.116 \mathrm{a}$ & $1.583 \mathrm{a}$ & $8.33 \mathrm{a}$ \\
\hline Infertile soil & $5.98 \mathrm{~b}$ & $1.75 \mathrm{~b}$ & $0.44 \mathrm{~b}$ & $0.27 \mathrm{a}$ & $0.263 a$ & $13.90 \mathrm{~b}$ & $5.90 \mathrm{a}$ & $0.100 \mathrm{~b}$ & $1.228 \mathrm{~b}$ & $6.67 \mathrm{~b}$ \\
\hline LSD (0.05) & 0.620 & 0.188 & 0.120 & NS & NS & 0.558 & NS & 0.010 & 0.074 & 0.692 \\
\hline $\mathrm{CV}(\%)$ & 6.3358 & 7.1494 & 13.9288 & 20.2556 & 14.1280 & 2.6826 & 1.4578 & 6.9612 & 3.7491 & 6.5295 \\
\hline \multicolumn{11}{|l|}{ Soil Depth } \\
\hline $0-15 \mathrm{~cm}$ & $6.71 \mathrm{a}$ & $1.76 \mathrm{~b}$ & $0.57 \mathrm{a}$ & $0.27 \mathrm{a}$ & $0.251 \mathrm{a}$ & $14.48 \mathrm{a}$ & $5.93 \mathrm{a}$ & $0.112 \mathrm{a}$ & $1.365 b$ & $7.25 \mathrm{a}$ \\
\hline $15-30 \mathrm{~cm}$ & $7.12 \mathrm{a}$ & $1.96 \mathrm{a}$ & $0.65 a$ & $0.29 \mathrm{a}$ & $0.227 \mathrm{a}$ & $14.99 \mathrm{a}$ & $5.98 \mathrm{a}$ & $0.104 a$ & $1.447 \mathrm{a}$ & $7.75 a$ \\
\hline LSD (0.05) & NS & 0.188 & NS & NS & NS & NS & NS & NS & 0.074 & NS \\
\hline
\end{tabular}

*Values with the same letter are not significantly different ( $P$ < 0.05); Ca = Calcium; $M g=$ Magnesium; $K=$ Potassium; Na = Sodium; Ex. acidity = exchangeable acidity; $C E C=$ Cation Exchange Capacity; $T N=$ Total Nitrogen; OC=Organic Carbon; Av.P = Available Phosphorous; $N S=$ not significant; $L S D=$ Least Significance Difference; $C V=$ Coefficient of Variation

Table 6: Interaction effects of farmers' perception and soil depth on selected soil chemical properties

\begin{tabular}{|c|c|c|c|c|c|c|c|c|c|c|c|c|}
\hline \multirow[t]{4}{*}{ Variables } & \multicolumn{12}{|c|}{ Exchangeable $\left(\mathrm{cmol}(+) \mathrm{kg}^{-1}\right)$} \\
\hline & \multicolumn{2}{|c|}{$\mathrm{Ca}$} & \multicolumn{2}{|c|}{$\mathrm{Mg}$} & \multicolumn{2}{|r|}{$\mathrm{K}$} & \multirow{2}{*}{\multicolumn{2}{|c|}{$\frac{\mathrm{Na}}{\text { epth }(\mathrm{cm})}$}} & \multicolumn{2}{|c|}{ Exa.A } & \\
\hline & \multicolumn{8}{|c|}{ Soil depth $(\mathrm{cm})$} & & & \multicolumn{2}{|c|}{ CEC } \\
\hline & $0-15$ & $15-30$ & $0-15$ & $15-30$ & $0-15$ & $15-30$ & $0-15$ & $15-30$ & $0-15$ & $15-30$ & $0-15$ & $15-30$ \\
\hline Fertile soil & $7.47 \mathrm{a}$ & $8.29 \mathrm{a}$ & $1.81 \mathrm{~b}$ & $2.13 \mathrm{a}$ & $0.71 \mathrm{a}$ & $0.86 \mathrm{a}$ & $0.27 \mathrm{a}$ & $0.31 \mathrm{a}$ & $0.23 \mathrm{ab}$ & $0.19 \mathrm{~b}$ & $15.37 \mathrm{a}$ & $15.77 \mathrm{a}$ \\
\hline Infertile soil & $5.95 b$ & $6.02 b$ & $1.72 \mathrm{~b}$ & $1.79 \mathrm{~b}$ & $0.43 b$ & $0.44 \mathrm{~b}$ & $0.27 \mathrm{a}$ & $0.28 \mathrm{a}$ & $0.27 a$ & $0.26 \mathrm{ab}$ & $13.59 \mathrm{~b}$ & $14.22 \mathrm{~b}$ \\
\hline $\mathrm{LSD}(0.05)$ & \multicolumn{2}{|c|}{0.877} & \multicolumn{2}{|c|}{0.266} & \multicolumn{2}{|c|}{0.169} & \multicolumn{2}{|c|}{0.113} & \multicolumn{2}{|c|}{0.067} & \multicolumn{2}{|c|}{0.790} \\
\hline $\operatorname{SEM}( \pm)$ & \multicolumn{2}{|c|}{0.1928} & \multicolumn{2}{|c|}{0.0177} & \multicolumn{2}{|c|}{0.0072} & \multicolumn{2}{|c|}{0.0032} & \multicolumn{2}{|c|}{0.0011} & \multicolumn{2}{|c|}{0.1562} \\
\hline $\mathrm{CV}(\%)$ & \multicolumn{2}{|c|}{6.3358} & \multicolumn{2}{|c|}{7.1494} & \multicolumn{2}{|c|}{13.9288} & \multicolumn{2}{|c|}{20.2556} & \multicolumn{2}{|c|}{14.1280} & \multicolumn{2}{|c|}{2.6826} \\
\hline
\end{tabular}

Table 6 Continued

\begin{tabular}{|c|c|c|c|c|c|c|c|c|}
\hline \multirow[t]{4}{*}{ Variables } & \multicolumn{8}{|c|}{ Exchangeable $\left(\mathrm{cmol}(+) \mathrm{kg}^{-1}\right)$} \\
\hline & \multicolumn{2}{|c|}{$\mathrm{pH}-\mathrm{H}_{2} \mathrm{O}$} & \multicolumn{2}{|c|}{ Total Nitrogen $(\%)$} & \multicolumn{2}{|c|}{ Organic Carbon $(\%)$} & \multicolumn{2}{|c|}{ Av. Phosphorous(ppm) } \\
\hline & \multicolumn{8}{|c|}{ Soil depth $(\mathrm{cm})$} \\
\hline & $0-15$ & $15-30$ & $0-15$ & $15-30$ & $0-15$ & $15-30$ & $0-15$ & $15-30$ \\
\hline Fertile soil & $5.99 \mathrm{a}$ & $6.04 \mathrm{a}$ & $0.121 \mathrm{a}$ & $0.111 \mathrm{ab}$ & $1.562 \mathrm{a}$ & $1.604 \mathrm{a}$ & $8.17 \mathrm{a}$ & $8.50 \mathrm{a}$ \\
\hline Infertile soil & $5.88 \mathrm{a}$ & $5.92 \mathrm{a}$ & $0.103 b$ & $0.097 \mathrm{~b}$ & $1.168 \mathrm{c}$ & $1.289 \mathrm{~b}$ & $6.34 \mathrm{~b}$ & $7.00 \mathrm{~b}$ \\
\hline $\operatorname{LSD}(0.05)$ & \multicolumn{2}{|c|}{ NS } & \multicolumn{2}{|c|}{0.015} & \multicolumn{2}{|c|}{0.105} & \multicolumn{2}{|c|}{0.978} \\
\hline $\operatorname{SEM}( \pm)$ & \multicolumn{2}{|c|}{0.0075} & \multicolumn{2}{|c|}{0.0001} & \multicolumn{2}{|c|}{0.0028} & \multicolumn{2}{|c|}{0.2398} \\
\hline $\mathrm{CV}(\%)$ & \multicolumn{2}{|c|}{1.4578} & \multicolumn{2}{|c|}{6.9612} & \multicolumn{2}{|c|}{3.7491} & \multicolumn{2}{|c|}{6.5295} \\
\hline
\end{tabular}

*Values with the same letter are not significantly different $(P<0.05) ; A v .=$ Available; $L S D=$ Least Significance Difference; $S E M=$ Standard Error of Mean; $C V=$ Coefficient of Variation

All these physical and chemical properties of the soils were linked with the farmers' soil fertility management practices of the study sites. Farmers used oxen to pull the local plough material 'Maresha'. Most of the farmers in the study areas cultivate their land 2-3 times before planting cereals. The study area has two cropping seasons short rain season ('Ganna') and main rain season ('Bona') and only few farmers divided their land into 'Ganna' and 'Bona' cropping land. The main reasons raised by farmers for not using the land for double cropping was fear of soil fertility depletion as a result of double cropping.

Farmers of the study area are well aware of the advantage of returning crop residues to soil fertility. But, only few farmers around $12 \%$ retain most crop residues in their field. This is because crop residues are used as construction material, fuel and source of animal feed. Moreover, farmers used low rate of mineral fertilizers due to the current escalating prices of chemical fertilizers. $75 \%$ farmers broadcast/ apply only $50 \mathrm{~kg}$ diammonium phosphate /ha for cereals. This rate is by far lower than the blanket recommendation (100 kg diammonium phosphate and $50 \mathrm{~kg}$ urea) for the area.

The major practice followed by farmers in this area is to rotate barley and wheat on the same piece of land. However, few farmers in some part of the highland rotated cereals with leguminous crops (e.g. field pea, chick pea, and lentil). Despite the fact that farmers know the benefit of fallowing to restore soil fertility, study also clearly showed that long term fallowing was not practiced in the study area 
due to the ever increasing population pressure. Currently, the common practice in the area is seasonal fallowing i.e. leaving the land fallow for one or two seasons.

\subsection{Conclusion}

The results presented in this paper indicate that there is good agreement between assessment of soil fertility by farmers in Abuhoy Gara catchment and scientific indicators of soil fertility such as exchangeable cations, cation exchange capacity, soil organic carbon content, total nitrogen and $\mathrm{pH}$. The names the farmers give to soils do not necessarily correlate to the scientific classification because their classification and indicators rely on soil characteristics that they can practically experience. Nevertheless, both farmers and researchers have common objectives, mainly to ensure that the soil resources are sufficient and sustainable to meet the needs of farmers at present and in the future. In spite of the fact that different soil quality management practices that billions of trees have been planted, and millions of hectares of land treated through the construction of terraces, deep trenches, percolation ponds and others in the study area by the local government, there are still many areas untreated, some of the efforts have not succeeded. According to the response of interviewed farmers, this failure is believed to be due to inadequate capacity to implement relevant technologies at appropriate places which could be innovated by farmer's group research approach. As stated by Pawluk et al. (1992), researchers need to understand and use indigenous knowledge systems, which need to be viewed, not as opposing, but rather as complimentary to their own way of thinking. Therefore, it is important that both farmers' perception and researchers' scientific methodology of soil fertility assessment are used to give a sustainable solution to land degradation and soil fertility declining problems. And conserving and maintaining the soil quality is not only important for improvement of land productivity but also for climate crises mitigation through storing the world's carbon dioxide emissions and neutralizing or filtering out potential pollutants by well managed soils.

\section{Acknowledgement}

This work has been in its present shape with considerable professional, financial, and material inputs from various sources. Therefore, it is an amazing excitement to him to come to this final point and to express his deepest gratitude to all individuals and organizations who contributed directly or indirectly to this study and the production of these research findings. The author would like to express his sincere thanks to his University; Woldia University from the planning stage of the research work and funding to the production of this study output. His heartfelt thanks go to the Amhara National Regional State Sirinka Agriculture Center for offering him all possible helps in all aspects of the laboratory work. Apart from that, he wants to express his appreciation to the Gidan District Agriculture office staff members for their unlimited contribution from site selection all the way up to sample collection.

\section{References}

Alemneh Dejene (2003). Integrated natural resources managements to enhance food security: the cases for community- based approaches in Ethiopia. Food and Agricultural Organization (FAO), the United Nations.

Barber, S. (1984). Soil Nutrient Bioavailability: Mechanistic Approach. John Wiley and Sons. Inc., New York, USA.398p.

Brady, N.C. and Weil, R.R. (2002). The nature and properties of soils, $13^{\text {th }}$ Ed. Prentice- Hall Inc., New Jersey, USA. 960p.

Bremner, D. C. and Mulvaney, J. M. (1982). Total Nitrogen. In: Methods of Soil Analysis. (A. L. Page, R. H. Miller and D. R. Keaney, eds). Number 9 Part 2, Am. Soc. Of Agron.

Corbeels, M., Shiferaw, A. and Haile, M. (2000). Farmers' knowledge of soil fertility and local management strategies in Tigray, Ethiopia. Managing Africa's Soils 10, ii +23 .

Dasgupta, P. and Mäler, K.G. (1994). Poverty, institutions and the environmental- resource base. World Bank environment paper 9, Washington, DC 
FAO (Food and Agriculture Organization) (2006). Plant nutrition for food security: A guide for integrated nutrient management. FAO, Fertilizer and Plant Nutrition Bulletin 16, Rome, Italy.

Hugo, L.P., Johann, B., Juergen, G., Hiremagalur, G., Mohammad, J., Victor, M., et al. (2002). Linking Natural Resources, Agriculture and Human Health: Case Studies from East Africa. LEISA Magazine supplement, page 17- 20.

Gee, G.W. and Bauder, J.W. (1986). Particle Size Analysis. In: Methods of Soil Analysis, Part A. Klute (ed.). 2 Ed., Vol. 9 nd. Am. Soc. Agron., Madison, WI, pp. 383-411.

Jones, J.B. (2003). Agronomic Handbook: Management of Crops, Soils, and Their Fertility. CRC Press LLC, Boca Raton, Florida, USA. 482p.

Kuo, S. (1996). Phosphorus. In: Method of Soil Analysis. Part 3.Chemical Methods, Sparks, D.L., A.L. Page, P.A. Helmke, R.H. Leoppert and P.N. Soltanpour, et al. (Eds.), Soil Science Society America, Inc. and America Soc. Agronomy, Inc., Wisconsin, ISBN-10: 0891188258, pp. 869-919.

Landon, J.R. (Ed.) (1991). Booker tropical soil manual: A Handbook for Soil Survey and Agricultural Land Evaluation in the Tropics and Subtropics. Longman Scientific and Technical, Essex, New York. $474 \mathrm{p}$.

McLean, E.O. (1982). Soil pH and lime requirement. In: Methods of soil analysis, Part 2. (Edited by A.L. Page, R.H. Miller and D.R. Keeney). American Society of Agronomy, Madison, Wisc, pp. 199224.

Murage, E.W., Karanja, N.K., Smithson, P.C. and Woomer, P.L. (2000). Diagnostic indicators of soil quality in productive and non- productive smallholders' fields of Kenya's Central Highlands. Agric. Ecosyst. Environ. 79, pp. 1-8.

Murphy, H.F. (1968). A report on fertility status and other data on some soils of Ethiopia. College of Agriculture, HSIU. Experimental Station Bulletin No. 44, College of Agriculture, Alemaya, Ethiopia: $551 \mathrm{p}$.

Nelson, D.W. and Sommers, L.E. (1982). Total carbon, organic carbon and organic matter: In: A.L. Page, R.H. Miller and D.R. Keeney) Methods of soil analysis. Part 2 Chemical and Microbiological Properties, pp. 539-579.

Okalebo, J.R., Gathua, K.W. and Woomer, P.L. (1993). Laboratory methods of soil and plant analysis: A working manual - KARI - UNESCO - ROSTA, pp. 88.

Olsen, S.R., Cole, C.V., Watanabe, F.S. and Dean, L.A. (1954). Estimation of available phosphorus in soils by extraction with sodium carbonate. USDA Circular, 939, pp. 1-19.

Pawluk, R.R., Sandor, J.A., and Tabor, J.A. (1992). The role of indigenous soil knowledge in agricultural development. J. Soil Water Conserv. 47, pp. 298-302.

Ryan, J., Estefan, G., and Rashid, A. (2001). Soil and plant analysis lab manual. 2nd ed. International Center for Agricultural Research in the Dryland Areas (ICARDA), Aleppo, Syria. National Agricultural Research Center, Islamabad, Pakistan.

Saggar, S., Tate, K.R., Feltham, C.W., Childs, C.W. and Parshotam, A. (1994). Carbon turnover in a range of allophonic soils amended with ${ }^{14} \mathrm{C}$-labelled glucose. Soil Biology and Biochemistry, 26, pp. 1263-1271. 
Saggar, S., Parshotam, A., Sparling, G.P., Feltham, C.W. and Hart, P.B.S. (1996). ${ }^{14}$ C-labelled ryegrass turnover and residence times in soils varying in clay content and mineralogy. Soil Biology and Biochemistry, 28, pp. 1677-1686.

Shrestha, B., Maskey, S.L., Shrestha, R.K., Tripathi, B.P., Khadka, Y.G., Munankarmi, R.C., et al. (2000). Soil fertility management: farmers' practices and perception in the hills of Nepal. Lumle Technical Paper No. 2000/4. Lumle Agriculture Research Station, Pokhara, Nepal.

Sumner, M.E. and Stewart, B.A. (1992). Soil Crusting: Chemical and Physical Processes. $1^{\text {st }}$ Edn., Lewis Publishers, Boca Raton, ISBN-10: 0873718690, pp. 372.

Tekalign Tadese (1991). Soil, plant, water, fertilizer, animal manure and compost analysis. Working Document No. 13. International Livestock Research Center for Africa, Addis Ababa, Ethiopia.

World Bank (2008). Sustainable Land Management Project, Project Appraisal Document (PAD), Ethiopia/Report No 42927-ET, Project I.DP107139,http://www-wds.worldbank.org/external/projects/. 